DOI: 10.12731/2658-4034-2020-6-31-54

УДК 159.9.075

\title{
МУЖЧИНА И ЖЕНЩИНА В ПРОСТРАНСТВЕ КАРЬЕРНОГО ВЗАИМОВОСПРИЯТИЯ
}

\section{Савченко И.А., Козлова Ю.В.}

Раскрываются условия и формы реализации гендерных моделей в профессиональной среде, показывается сочиокультурная и личностная динамика трансляичи гендерных установок в российском обиестве.

На основе данных онлайн-опроса проводится анализ установок взаимного восприятия мужчин и женщин относительно преимуществ их семейного статуса и карьерного потенциала в условиях профессиональной среды современной организащии.

Цель исследования - изучение особенностей взаимного восприятия мужчин и женщин в прочессе карьерных отношений. В соответствии с иелью авторы ставят задачи: 1) проанализировать взгляды исследователей на проблему функиионирования гендерного фактора в процессе профессиональной социализации личности; 2) понять специфику взаимных аттитюдов мужчин и женщин в процессе карьерного взаимодействия; 3) посредством обобщения теоретического материала и эмпирических данных дать характеристику «гендерного климата» современной российской организации.

Методы и методология. В ходе работы над темой статьи используются классические методы познания общественных явлений, такие как анализ, обобщение, аналогия и сравнение. Применяется гендерный подход, который предполагает исследование системь взаимоотношений и взаимовосприятий мужчин и женщин в различных сферах общественной жизни (см. например, работь Б. Зибелл [23, p. 8]). Данный подход отличается от «женских исследований» 
и, тем более, от философии феминизма, где фокус научного внимания концентрируется на «женской тематике». Для получения эмпирических данных применен онлайн-опрос, проведенный с использованием гугл-форм.

Результаты. Дан анализ зарубежных и отечественных подходов к изучению карьерного прочесса. Охарактеризована карьера как социально-психологическое и сочиокультурное явление, выявлены сочиально-психологические предпосылки и динамика гендерного неравенства в современных условиях. На основании интерпретации данных опроса выявляются особенности взаимного восприятия мужчин и женщин в условиях их профессионального взаимодействия.

Область применения результатов. Результаты исследования могут использоваться в ичелях создания рекомендаций для изучения психологических составляющих состояния общественного мнения по управленческой и гендерной проблематике, для организаџии социально-значимых мероприятий, семинаров, вебинаров, включающих гендерную тематику, при написании учебных пособий социильнокоммуникативного блока.

Ключевые слова: мужчина; женшина; гендерные противоречия; карьера; конкуренция; ожидания; восприятие; снисхождение.

\section{MALE AND FEMALE IN THE SPACE OF CAREER MUTUAL PERCEPTION}

\section{Savchenko I.A., Kozlova Yu.V.}

The authors reveal the conditions and forms of implementation of gender models in the professional environment, show the socio-cultural and personal dynamics of awareness and translation of gender attitudes in Russian society.

Based on the survey data, the authors analyze the attitudes of mutual perception of men and women regarding the advantages of their family 
status and career potential in the professional environment of a modern organization.

The purpose of the study is to study the features of the mutual perception of men and women in the process of career relationships. In accordance with the goal, the authors set the following tasks: 1) to analyze the views of researchers on the problem of the functioning of gender in the process of professional socialization; 2) to understand the specifics of the mutual attitudes of men and women in the process of career interactions; 3) by a generalization of theory and empirical data to characterize the gender climate in modern Russian organizations.

Methods and methodology. In the course of working on the topic of the article, classical methods of cognition of social phenomena, such as analysis, generalization, analogy and comparison, are used. The gender approach is applied, which involves the study of the system of interactions, relationships and mutual perceptions of men and women in various spheres of public life (for example, the works by B. Zibell [23, p. 8]). This approach differs from "women's studies" and, even more so, from the philosophy of feminism, where the focus of scientific attention is concentrated on "women's topics". To obtain empirical data, we used an online survey conducted using Google forms.

Results. The analysis of foreign and domestic approaches to the study of the career process is given. Career is characterized as a socio-psychological and socio-cultural phenomenon, the prerequisites and dynamics of gender inequality in modern conditions are revealed. Based on the interpretation of the survey data, the features of the mutual perception of men and women in the conditions of their professional interaction are revealed.

The scope of the results. The results of the research can be used to create recommendations for studying the psychological components of the state of public opinion on management and gender issues, for organizing socially significant events, seminars, webinars, including gender topics, when writing textbooks for the social and communicative block.

Keywords: man; woman gender contradictions; career; competition; expectations; perceptions; condescension. 
В последние десятилетия происходит быстрая смена условий общественной жизни, стремительные социальные трансформации отражаются и на формах профессиональной самореализации наших современников. Во второй половине XX в. карьерный процесс стал по настоящему массовым, а начало XXI вывело его на новый уровень скорости, благодаря новым технологиям передачи информации и автоматизации трудовых функций. Карьера сегодня стала предметом многочисленных исследований в рамках социальной и дифференциальной психологии, психологии труда.

В отечественной психологической науке карьера преимущественно рассматривается как личностная реализация, что обусловлено длительным развитием данной проблематики в русле деятельностного подхода с акцентом на потребность личности в труде и социализации в трудовом коллективе (Г.И. Корчагина, Е.В. Макарова [10]), (Е.Е. Бочарова [3]), в последние десятилетия начинает применяться акмеологический (В.А. Толочек [18]) и системогенетический (С.Д. Гуриева [6]) подходы к изучению психологических проблем карьеры.

В зарубежных исследованиях карьеры тема самоопределения, самореализации, начиная с Абрахама Маслоу [12], традиционно имеет гуманистическую направленность категории «профессиональная самореализация», «профессиональная/карьерная успешность», «профессиональная направленность личности» раскрываются в связи с индивидуализацией карьерного пути.

Исследования социальных аспектов карьеры, конкуренции на рынке труда, социально-демографической детерминации карьеры связаны, прежде всего, с проблематикой управления, оптимизации организационных ресурсов, с вопросами социальной ответственности предприятий, организаций и бизнес-структур (О.Е. Белова, С.Д. Гуриева [2]), (Л.Г. Гарипова [5]).

Принцип социального равенства, обеспечения здоровой карьерной конкуренции как формы социализации, социального продвижения, отчасти в наши дни реализован в виде конкурсов на должность, периодических аттестаций, в измерении коэффициента трудового 
участия сотрудника, оценки работников по должностным компетенциям (KPI).

Карьерное продвижение как способ повышения социального статуса и форма личностной реализации - та область, которая в наше время стала максимально востребованной. Произошло это вследствие демократизации общественной системы, трансформации институтов государства, религии, семьи. Карьера стала максимально привлекательным способом структурирования времени, потоков информации, элементов сознания. Сам по себе профессиональный и должностной статус, общественное поощрение, да и финансовая защищенность, а тем более независимость - важная, но не единственная причина мотивации женщин к конкуренции с мужчинами. Также и компенсаторное поведение, направленное на восполнение функций обеспечения, защиты, принятия решений не является для современной женщины объективной необходимостью.

В данной статье рассматриваются гендерные аспекты карьерной конкуренции. Социокультурные трактовки понятий «гендерный эталон», «гендерные стереотипы», «гендерные ожидания», «фемининное и маскулинное поведение», развиваются в ответ на серьезные общественные перемены. В первую очередь это касается института брака и карьерного процесса современных мужчин и женщин.

В междисциплинарном изучении карьерного процесса рассматриваются следующие аспекты: развитие личности в профессии, в том числе в организационном и должностном контексте; взаимодействие с отдельными слоями социума в процессе движения по карьерной траектории; индивидуально-типические, социальнокультурные предпосылки профессиональной эволюции, способности, значимые для этого процесса и в нем развивающиеся [19; 221]. На развитие карьеры оказывает влияние система факторов, одни из которых действуют через другие, формируя адаптивность в профессиональной среде, уровень стабильности карьеры (продолжительность стажа, длительность работы в должности, в организации), длинные, средние и короткие карьерные циклы (Анс Ве Вос, Беатрис Ван дер Хейден [22]). 
Так, поведение женщины в контексте построения карьеры может быть построено на стратегии акцентирования своей гендерной принадлежности или же на ее отрицании (Doing \& Undoing Gender Strategies), при этом акцентирование женственности (в шести вариантах поведения) чаще используется во взаимодействии с вышестоящими лицами. А вот «отрищать свой гендер» склонны лишь около трети женщин и эта стратегия - для горизонтальных коммуникаций, она более вариативна (до 13 вариантов). Как отмечают С.Д. Гуриева и У.А. Удавихина, лишь сочетание стратегий, которое встречается реже всего, делает поведение женщины более разнообразным и способствуют карьерному успеху [6, с. 270].

Внутренняя среда организации может в разной степени актуализировать гендерную идентификацию, в том числе - как карьерное препятствия, продуцировать ситуации, требующие воспроизведения гендера или же конфронтации с ним. Акцентирование гендера выражается не только в особенностях внешнего вида и стиля, но и в эмоциональной аргументации, ориентированности на неформальное взаимодействие и поддержку. Игнорирование своей гендерной принадлежности в поведении связано с уверенностью, последовательностью, логической направленностью и формализацией контактов, при этом женщина воспринимается как ориентированная на карьерный рост и получает меньше поддержки коллег [6, с. 272].

В ряде организаций, подразделений преобладают чисто женские коллективы, в которых более распространены «мужские» карьерные стратегии, отрицание телесности и наиболее жесткие способы контроля за профессиональным поведением. Для эффективного управления человеческими ресурсами, профилактики профессиональной деформации личности целесообразен «микроподход» (см. работу Е.Ю. Погудиной [13, с. 173-174]), предполагающий, по уточнению С.В. Гуцыковой [7, с. 131], учет психофизических показателей, гендерных и возрастных аспектов поведения, создание действенной мотивации, применение «эмоционального менеджмента» для управления лояльностью и компетентностью сотрудников. 
Отношение к труду и уровень удовлетворенности условиями работы в России, как отмечают некоторые Г.Ф. Ромашкина и Ю.В. Ушакова, в большей степени зависит от специфики деятельности и типа организационной среды, нежели от возраста, пола и уровня образования [14, с. 194]. Это расширяет диапазон средств управления человеческими ресурсами в организации и набор карьерных траекторий в структурах разных типов.

В смешанных по гендерному составу организациях женщины нередко субъективно осознают пол как препятствие к карьерному росту, сталкиваются с неравенством, микроагрессией, а также травмирующими указаниями на пол (Т.В Казанцева и др. [8, с. 34]). Не случайно трудности с формированием профессиональной репутации, достижением уважения и поддержки экспертности, выбор в пользу мужчин при повышении и определении норм оплаты труда так или иначе отмечают более половины женщин [8, с. 42].

Взаимодействие в профессиональном контексте в ряде случаев приводит женщину к вынужденному осознанию своего пола [8, c. 43-44]. Это выражается как проявление гендерной дискриминации в выборе способов решения рабочих задач и партнеров по работе; снижение доверия как к профессионалу в связи с материнством; сексуальные коннотации в деловом общении; прямое указание на пол.

Принудительная форма указаний на пол («Ты же женщина!») во всех вариантах применяется как средство давления, как способ переключить взаимодействие с делового уровня на физический, подвергает сомнению компетентность и профессионализм женщины (врачебная, предпринимательская, юридическая сфера) или же предъявляет эталоны фемининности, которым, безусловно, следует соответствовать (внешний вид, поведение, жизненные цели, обязанности). Пол может быть обоснованием поручить рутинную работу - как более ответственному, но менее самостоятельному работнику. Шутливые указания на пол используются для сглаживания конфликтов, повышения самооценки и самоуважения мужчин. Тактически, женщина может получать таким образом преимущества, но в стратегическом плане женщины воспринимают пол как 
карьерное препятствие. Именно характер эмоциональной реакции определяет наличие гендерного неравенства в организации. Там, где женщины воспринимают подобные указания положительно и нейтрально, действуют универсальные для общества культурные нормы. Там, где возникает отрицательная реакция, неравенство в организации жестче, чем в обществе в целом [8, с. 45-49]. Если половая принадлежность становится карьерным и профессиональным барьером, возможно, следует начать с признания ситуации неравенства, в том числе, - замаскированной под доброжелательность и поддержку.

Показательно, что в постсоветском пространстве женщина на пути к успеху вынуждена «сопротивляться гендеру», традиционным образцам поведения и участвовать в карьерной гонке, именно для компенсации «несостоявщейся маскулинности» мужчины (Л.Г. Гарипова [5], О.А. Воронина [4]). Следует отметить, что советская система общественного воспитания и образования была направлена на формирования «советского человека», ориентированного на коллектив, общественно значимую трудовую активность, равенство полов на всех возрастных этапах. Система дошкольного и среднего образования создавала предпосылки к тому чтобы женщины учились, работали, участвовали в общественной жизни. Общество поощряло в женщине проявление эталонных мужских качеств (решительности, активности, созидательности и т д). Уже в 1960-е годы XX века в жизнь вступило послевоенное поколение мальчиков которые воспитывались в условиях демографического перевеса в сторону женщин. В последующие десятилетия в семье с маскулинной (властной) мамой, зачастую еще и неполной, выросло несколько поколений. Доминантным в обществе стало убеждением о том что женщинам приходится конкурировать за мужчину для создания семьи, одновременно конкурируя с мужчинами и другими женщинами в профессиональной сфере.

В итоге уже к 1980-м годам феминизация мужчин стала хорошо заметной, эта проблема нашла отражение в отечественной психологии, активно изучалось понятие «полоролевой идентификации» 
как синонимичное «гендеру» (работы И.С. Кона, Я.Л. Коломинского, В.А. Ядова).

«Вторая волна» модификации гендерных стандартов пришла уже в начале нынешнего века, когда широко стал внедряться западный менеджмент и идеи феминизма. В середине 2010-х годов «окно закрылось», однополые отношения и браки, а следом за ними агрессивный феминизм, перестали быть «модными» и социально поощряемыми, но идея, что «женщине для того, чтобы добиться успеха нужно вдвое больше способностей, знаний и труда - осталась. На постсоветском пространстве сохраняется и усиливается стремление женщин ориентировать своих дочерей на карьеру и экономическую независимость, на активное участие в конкуренции на рынке труда. Подчас семейное воспитание полностью ориентировано на будущую карьеру. Именно в этой конкуренции женщина так часто сталкивается с неравенством: от открытого сексизма до понижения собственной значимости. Вероятно, глубинные причины подобного явления связаны не только с экономическими и общественными процессами, но и с архетипическими, с реализацией бессознательных трансферов (О.А. Хасбулатова [21], И.А. Савченко [16]).

Немаловажную роль играют и активные вбросы масс-медиа, особенно - в условиях неопределенности и повышенной тревожной готовности (Ю.В. Козлова и др. [9]). Долгосрочные карьерные установки первых десятилетий XXI века сменяются стратегиями выживания, конкуренция растет, в этих условиях рутинные стратегии карьерного поведения более надежны и востребованы. Но это не исключает и инновационной стратегии, которая может выражаться в выработке нового поведения в семье и профессии, совмещения публичных ролей (как это происходит, например, у успешных блогеров, в тематических коммьюнити). Становится распространенным создание новых «женских» типов организаций, «женского бизнеса», основанного на обмене и социальной поддержке. Вместе с тем, развитие у женщины маскулинных качеств, считает Л.Г. Гарипова, неизбежно приводит к снижению этих качеств у мужчин, психологической напряженности в семье, двойной занятости жены и матери [5, с. 22]. 
В организациях государственной, гражданской и муниципальной службы представлены, по классификации А.М, Бекарева и Е.А. Лазуковой, несколько карьерных типов: сотрудники, не стремящиеся к продвижению и довольные своей должностью («удовлетворенные индифференты); те, кто довольны должностью, но стремятся к повышению профессионального статуса («удовлетворенные профессионалы»); ориентированные на должностной рост «удовлетворенные карьеристы»; неудовлетворенные должностью и стремящиеся к росту «неудовлетверенные карьеристы» и решившие прекратить карьеру «неудовлетворенные индифференты» [1, с. 162].

Показательно, что в формализованной сфере госслужбы и в высокоспециализированных отраслях с высокой степенью персональной ответственности мужчины и женщины выбирают сходную карьерную направленность (И.А. Савченко, В.В. Горбачев [17, с. 154]), в то время как в среднеспециализированных (служащие) отраслях степень карьерных притязаний женщин снижается. То есть в бюрократических структурах женщины чувствуют себя более комфортно в карьерном процессе, нежели в высокоспециализированной профессиональной среде, где личностный статус, личная компетентность и реальные достижения не являются суммарными, не поддерживаются должностными или властными полномочиями [1, с. 165].

Эмпирическую основу нашего эмпирического исследования составили результаты онлайн-опроса на основе гугл-форм. Опрос был направлен на выявление особенностей взаимного и ауто-восприятия мужчин и женщин в процессе их карьерного взаимодействия. Опросное исследование проводилось среди жителей г. Нижнего Новгорода в июне - ноябре 2020 года. Выборка $(n=1059)$ - квотная, пропорциональная основным социально-демографическим параметрам (кроме лиц моложе 18 лет). Возраст респондентов: 18 - 78 лет (18\% - 18-25 лет, 25\% - 26-35 лет, 25\% - 36-45 лет, 22\% - 4660 лет, 10\% - 61-78 лет). Все опрошенные - граждане Российской Федерации. Количество лиц мужского пола в выборке составило $42 \%$, женского - 58\%. Выборка является целевой: все респонденты работают в учреждениях (государственных, бюджетных, коммер- 
ческих), где функциональные обязанности мужчин и женщин не дифференцированы. Опрошенные заняты образовательной (35\%), офисной (44\%) и торговой деятельностью (21\%). Статистическая обработка данных была осуществлена автоматически, оформление данных исследования в виде таблиц в той форме, как они представлены в публикации, проводилось авторами «вручную».

\section{Результаты опроса и их обсуждение}

Принципиальным является мнение о том, что отношение женщины к трудовой деятельности, по мнению большинства мужчин $(65 \%)$ должно быть на уровне ответственного исполнителя, с чем согласны и $37 \%$ самих женщин. Еще четверть опрошенных мужчин допускают равнозначную вовлеченность мужчины и женщины в карьерную динамику, как и 44\% женщин (таблицы 1, 2).

Таблица 1.

Мнение мужчин и женщин об идеальном варианте отношения женщины к трудовой деятельности (\%)

\begin{tabular}{|c|l|l|l|}
\hline $\begin{array}{c}\text { № } \\
\text { п/п }\end{array}$ & \multicolumn{1}{|c|}{$\begin{array}{c}\text { Идеальный вариант отношения } \\
\text { женщины к трудовой деятельности } \\
\text { (возможен только один ответ) }\end{array}$} & Мужчины & Женщины \\
\hline 1 & $\begin{array}{l}\text { Женщина работает наравне с мужчиной и делает } \\
\text { карьеру }\end{array}$ & 25 & 44 \\
\hline 2 & $\begin{array}{l}\text { Женщина работает наравне с мужчиной, она } \\
\text { ответственна, но не стремится сделать карьеру }\end{array}$ & 65 & 37 \\
\hline 3 & $\begin{array}{l}\text { Женщина работает без самоодачи, Ее основные } \\
\text { интересы - вне работы }\end{array}$ & 10 & 19 \\
\hline
\end{tabular}

Таблича 2.

Мнение мужчин и женщин об идеальном варианте отношения мужчины к трудовой деятельности (\%)

\begin{tabular}{|c|l|l|l|}
\hline $\begin{array}{c}\text { № } \\
\text { п/п }\end{array}$ & $\begin{array}{c}\text { Идеальный вариант отношения } \\
\text { мужчины к трудовой деятельности } \\
\text { (возможен только один ответ) }\end{array}$ & Мужчины & Женшины \\
\hline 1 & Карьера - главное для мужчины & 50 & 54 \\
\hline 2 & $\begin{array}{l}\text { Ответственный работник, но не стремится } \\
\text { сделать карьеру }\end{array}$ & 35 & 42 \\
\hline 3 & $\begin{array}{l}\text { Работает без самоотдачи, его основные } \\
\text { интересы - вне работы }\end{array}$ & 15 & 4 \\
\hline
\end{tabular}


Мнение о том, что повышение профессионализма, совершенствование выполнения должностных обязанностей, адаптация к организационным изменениям составляют фундамент карьерного развития «по горизонтали», мужчина и женщина на этом уровне у большинства опрошенных получают одобрение. Ориентированность женщины только на семью разделяют 19\% женщин и 10\% мужчин, а сторонниками карьерного равенства полов являются 44\% женщин и $25 \%$ мужчин. Стоит отметить, что женщины более склонны поддерживать карьерный рост как жизненный приоритет мужчин $(54 \%)$ и возможность развиваться в этом наравне с ними (44\%). Тогда как только 50\% опрошенных мужчин считает, что для них самих карьера - главное в жизни.

Такая картина во много обусловлена устойчивым демографическим дисбалансом, который в старших возрастных группах усиливается. А также и патерналистскими установками, доминировавшими в российском обществе вплоть до 90-х годов XX-го века. Образ женщины-руководителя, политического или общественного деятеля, ученого чаще всего формировался как калька с мужских образов. В то же время стереотип о доминировании ориентации лишь на ограниченную семейную самореализацию окончательно ушел уже в 60-е годы прошлого века, поскольку на женщину была возложена реализация типично мужских функций и моделей профессионального поведения в дополнение к традиционным моделям, ориентированным на семью.

Наш вопрос о семейном статусе как факторе профессиональной и карьерной успешности (таблицы 3,4 ), нужно признать, сам по себе является дискуссионным, так как напрямую связан с традиционной моделью семьи и полоролевого поведения в возрастной динамике. С одной стороны, принадлежность с семейно-родовой структуре делает профессиональную мотивацию устойчивой, предсказуемой, позволяет организации перспективно планировать кадровый резерв. С другой стороны, социальная мобильность как мужчин, так и женщин, готовность выбирать и поддерживать новые модели реализации родительско-семейной функции (для родившихся в се- 
редине 1980-х годов и позже) - уже признак успешности, личной эффективности. Привлекательна идея «построить жизнь «так, как я хочу», в соответствии со своими возможностями и убеждениями», используя карьеру как один из инструментов достижения желаемого. Так, по данным опроса, семейный статус не отражается на качестве работы женщины по мнению 28\% женщин, а 49\% мужчин имеют то же мнение относительно мужчин. Сходная тенденция и в оценке не состоящих в браке и бездетных, которых потенциально успешными работниками считают $22 \%$ мужчин и $12 \%$ женщин. Подобный плюрализм отражает нарождающуюся тенденцию ослабления семейно-общинной традиции администрирования, в целом характерной для России.

Таблицуа 3.

Мнение мужчин и женщин о семейном статусе женщины, имеющей наибольшие шансы стать отличным работником (\%)

\begin{tabular}{|c|l|l|l|}
\hline $\begin{array}{c}\text { № } \\
\text { п/п }\end{array}$ & $\begin{array}{c}\text { У какой женщины } \\
\text { больше шансов стать отличным работником } \\
\text { (возможсен только один ответ) }\end{array}$ & Мужчины & Женщины \\
\hline 1 & Замужней женщины с ребенком (с детьми) & 18 & 25 \\
\hline 2 & Замужней женщины без детей & 25 & 10 \\
\hline 3 & $\begin{array}{l}\text { Незамужней (разведенной) женщины с ребенком } \\
\text { (с детьми) }\end{array}$ & 16 & 25 \\
\hline 4 & Незамужней (разведенной) женщины без детей & 22 & 12 \\
\hline 5 & $\begin{array}{l}\text { Семейный статус никак не влияет на качество } \\
\text { работы женщины }\end{array}$ & 19 & 28 \\
\hline
\end{tabular}

Таблица 4.

Мнение мужчин и женщин о семейном статусе мужчины, имеющим наибольшие шансы стать отличным работником (\%)

\begin{tabular}{|c|l|l|l|}
\hline $\begin{array}{c}\text { № } \\
\text { п/п }\end{array}$ & $\begin{array}{c}\text { У какого мужчины } \\
\text { больше шансов стать отличным работником } \\
\text { (возможен только один ответ) }\end{array}$ & Мужчины & Женщины \\
\hline 1 & Женатого мужчины с детьми & 16 & 23 \\
\hline 2 & Женатого мужчины без детей & 11 & 25 \\
\hline 3 & Неженатого (разведенного) мужчины с детьми & 6 & 2 \\
\hline 4 & Неженатого (разведенного) мужчины без детей & 18 & 25 \\
\hline 5 & $\begin{array}{l}\text { Семейный статус никак не влияет на качество } \\
\text { работы мужчины }\end{array}$ & 29 \\
\hline
\end{tabular}


Тема снисходительного отношения к работнику в зависимости от его пола (таблицы 5 и 6) почти единодушно интерпретируется как допустимая, причем наибольшую лояльность проявляют женщины по отношению к мужчинам (84\% готовы поддерживать и понимать упущения в их работе), в то время как большинство мужчин (53\%) готовы проявить снисходительность по отношению к коллеге-женщине. В этом с ним согласны 45\% женщин, если речь идет о коллеге-женщине, не претендующей на лидерство и карьерный рост. При этом сами мужчины не признают снисходительного отношения себе (62\%), подчеркивая тем самым значимость конкуренции между собой и по отношению к коллегам-женщинам.

Таблицуа 5.

Мнение мужчин и женщин о возможном снисхождении к женщине как к работнику (\%)

\begin{tabular}{|l|l|l|l|}
\hline $\begin{array}{c}\text { № } \\
\text { п/п }\end{array}$ & $\begin{array}{l}\text { Заслуживает ли женщина как «слабый пол» } \\
\text { какого-либо снисхождения на работе? } \\
\text { (возможен только один ответ) }\end{array}$ & Мужчины & Женщины \\
\hline 1 & $\begin{array}{l}\text { Раз уж женщина решила работать, пусть трудится } \\
\text { наравне с мужчиной. Никаких снисхождений }\end{array}$ & 35 & 25 \\
\hline 2 & $\begin{array}{l}\text { Работающая женщина заслуживает снисхождения } \\
\text { и понимания, но лишь случае, если она не } \\
\text { карьеристка и не стремится к руководящим } \\
\text { должностям }\end{array}$ & $\begin{array}{l}\text { Считаю, что работающая женщина как «слабый } \\
\text { пол» в любом случае заслуживает снисхождения } \\
\text { и помощи }\end{array}$ & 12 \\
\hline \multicolumn{2}{|l}{}
\end{tabular}

Таблицуа 6.

Мнение мужчин и женщин о возможном снисхождении к мужчине как к работнику (\%)

\begin{tabular}{|l|l|l|l|}
\hline $\begin{array}{c}\text { № } \\
\text { п/п }\end{array}$ & \multicolumn{1}{|c|}{$\begin{array}{c}\text { Заслуживает ли женщина } \\
\text { какого-либо снисхождения на работе? } \\
\text { (возможсен только один ответ) }\end{array}$} & Мужчины & Женщины \\
\hline 1 & $\begin{array}{l}\text { Ни о каких снисхождениях к мужчине не может } \\
\text { быть и речи }\end{array}$ & 62 & 16 \\
\hline 2 & $\begin{array}{l}\text { Мужчины заслуживают снисхождения. Их и так } \\
\text { немного в нашем городе и в нашей организации }\end{array}$ & 38 & 84 \\
\hline
\end{tabular}

Полностью отказывают женщине в каком-либо снисходительном отношении при выполнении профессиональных обязанностей 
$35 \%$ мужчин и 25\% женщин, в этих группах представители обоих полов воспринимаются как равноправные конкуренты в карьерном процессе.

Такой результат иллюстрирует тенденцию расхождения знаемого и значимого у большинства опрошенных. Очевидно, что за 30 лет, прошедших с момента распада СССР, где декларировалось полное равноправие полов (и оно во многом поддерживалось обращением «товарищ», системой образования, демонстрацией образцов эталонного поведения «советской женщины», прежде всего, в профессиональной и общественной сфере), кардинальных изменений в гендерных моделях не произошло [15].

Можно говорить об изменении установок относительно возраста и большей распространенности отношений вне брака. Но, тем не менее, женщины все так же занимают критичную позицию по отношению к своему полу и более терпимую, опекающую - по отношению к мужчинам.

В вопросе о том, как семейная ситуация может повлиять на готовность проявить снисходительность к работнику (таблицы 7 и 8, количество ответов на данный вопрос было не ограничено), было выявлено противоречие. Так, 22\% женщин и 22\% мужчин (таблица 7) считают, что «на работе все равны», если речь идет о снисхождении к женщине как к работнику. Если же ставится вопрос о снисходительности к мужчине как к работнику (таблица 8), то «за равенство» выступают лишь 5\% мужчин и 19\% женщин. Принимая во внимание, что на вопросы (таблицы 7 и 8) отвечают одни и те же люди, мы можем зафиксировать их «двойственную позицию»: «все равны, но мужчины равнее». Ситуацию, в которой $84 \%$ женщин (в таблица 6) готовы закрывать глаза на недоработки мужчин и делать что-то за них, когда и мужчины, и женщины относятся к мужчинам «с большим пониманием и эмпатией», чем к женщинам, мы можем описывать как ситуацию «ментального карьерного неравноправия». Иными словами, стереотипы о неодинаковости картерных функций живут в психике людей, в их сознании и бессознательном. 
Таблица 7.

Мнение мужчин и женщин о семейных обстоятельствах женщины, при которых можно стать снисходительным к ней как к работнику (\%)

\begin{tabular}{|c|l|l|l|}
\hline $\begin{array}{c}\text { № } \\
\text { п/п }\end{array}$ & $\begin{array}{l}\text { Вбстоятельства позволяют ей рассчитывать } \\
\text { на помощь и снисхождение на работе } \\
\text { (количество ответов не ограничено) }\end{array}$ & Мужчины & Женщины \\
\hline 1 & $\begin{array}{l}\text { Если она одинока, и ей нужно «устраивать } \\
\text { личную жизнь» }\end{array}$ & 12 & 4 \\
\hline 2 & $\begin{array}{l}\text { Если ее супруг требует повышенного внимания } \\
\text { и заботы }\end{array}$ & 6 & 6 \\
\hline 3 & Если у нее муж и ребенок (дети) & 18 & 14 \\
\hline 4 & Если она одна воспитывает ребенка (детей) & 11 & 25 \\
\hline 5 & $\begin{array}{l}\text { Если она замужем и является многодетной } \\
\text { матерью }\end{array}$ & 22 & 12 \\
\hline 6 & $\begin{array}{l}\text { Если она не замужем и является многодетной } \\
\text { матерью }\end{array}$ & 25 & 12 \\
\hline 7 & Если она заботиться о больном ребенке & 25 & 19 \\
\hline 8 & $\begin{array}{l}\text { Если она заботиться о больном родственнике } \\
\text { муже, родителе) }\end{array}$ & 15 & 14 \\
\hline 9 & $\begin{array}{l}\text { Считаю, что на работе мы все равны. Никто ни } \\
\text { за кого не обязан работать. Поэтому никто ни на } \\
\text { какое снисхождение рассчитывать не может }\end{array}$ & 22 & 22 \\
\hline
\end{tabular}

Если обобщить данные, представление в таблицах 5-8, можно выявить определенное противоречие: не менее 10\% опрошенных декларируют профессиональное равенство, при этом, однако, ожидают снисходительного отношения к себе самим (напомним, что $38 \%$ мужчин выразили одобрение идеи снисхождения к ним самим, $30 \%$ женщин готовы к тому, что к ним будут снисходительны как к работнику, 84\% женщин готовы проявлять снисходительность к мужчинам). Особенно сильно расходятся высокая готовность женщин оказывать поддержку мужчинам с низкой готовностью оказывать ее представительницам своего пола. Трудовые ориентации, придающие направление карьерному пути в контексте жизненного пути, могут быть восприняты личностью как необходимость или как призвание [26]. 
Таблиц̧а 8.

Мнение мужчин и женщин о семейных обстоятельствах мужчины, при которых можно стать снисходительным к нему как к работнику (\%)

\begin{tabular}{|c|l|l|l|}
\hline $\begin{array}{c}\text { № } \\
\text { п/п }\end{array}$ & $\begin{array}{c}\text { В каком случае семейные } \\
\text { обсятельства позволяют ей рассчитывать } \\
\text { на помощь и снисхождение на работе } \\
\text { (количество ответов не ограничено) }\end{array}$ & Мужчины & Женщины \\
\hline 1 & $\begin{array}{l}\text { Если он одинок, и ему нужно «устраивать } \\
\text { личную жизнь» }\end{array}$ & 18 & 2 \\
\hline 2 & $\begin{array}{l}\text { Если его супруга требует повышенного } \\
\text { внимания и заботы }\end{array}$ & 8 & 2 \\
\hline 3 & Если у него жена и дети & 44 & 15 \\
\hline 4 & Если он один воспитывает ребенка (детей) & 15 & 22 \\
\hline 5 & Если он женат и является многодетным отцом & 35 & 35 \\
\hline 6 & $\begin{array}{l}\text { Если он не женат и является многодетным } \\
\text { отцом }\end{array}$ & 35 & 40 \\
\hline 7 & Если он заботиться о больном ребенке & 27 & 19 \\
\hline 8 & $\begin{array}{l}\text { Если он заботиться о больном родственнике } \\
\text { (муже, родителе) }\end{array}$ & 15 & $\begin{array}{l}\text { Никто ни за кого ни при каких обстоятельствах } \\
\text { не обязан работать. Поэтому никто ни на какое } \\
\text { снисхождение рассчитывать не может. Считаю, } \\
\text { что на работе все равны. }\end{array}$ \\
\hline
\end{tabular}

На первый взгляд, сегодня приобретение трудовых компетенций («карьерных якорей»), в числе которых профессиональная независимость, защищенность, владение операционным и управленческим функционалом, предприимчивость, креативность, жизненный стиль, доступно каждому, независимо от гендерной принадлежности и полоролевой идентификации [25, с. 184]. Между тем, данные мировой статистики на 2020 год свидетельствуют, что для достижения гендерного паритета потребуется не менее столетия. И это связано не только с культурными эталонами и национальными традициями, но в большей степени имеет экономическое оправдание [24]. «Ролевая модель» эффективна и приносит экономию оплаты труда. Кроме того, по всей видимости, автоматизированы в связи с пандемией будут многие отрасли, в которых по всему миру трудятся женщины. 


\section{Выводы}

1. Анализ научных исследований по гендерной проблематике, а также результаты эмпирического исследования, направленного на изучение взаимного восприятия мужчин и женщин в условиях работы современной организации, в целом, подтвердили существование устойчивых стереотипов маскулинности - фемининности, сформированных еще в советскую эпоху. В целом, эти стетеотипы сводятся к тому, что мужчина сохраняет лидерские позиции и ориентирован на карьеру, в то время как женщина балансирует между профессией и семьей, при этом, желательно, не претендуя на особые достижения в карьере. Вместе с тем, существуют нюансы организационного «гендерного климата», выявление которых представляет научный интерес и содержат в себе элементы новизны.

2. Установлено, что в гендерном отношении привилегированность мужчин сводится не столько к поддержанию их маскулинного карьерного статуса, сколько в более снисходительном отношении к ним как к работникам со стороны как мужчин, так и женщин.

3. Показано, что завышенные требования к таким качествам женщин-работников, как организованность, ответственность и исполнительность предъявляют, в первую очередь не мужчины, а сами женщины. Именно женщины в своем большинстве склонны поддерживать, скорее, карьерное доминирование мужчины, нежели мириться с карьерным ростом других женщин - своих коллег. В подобных условиях и женщины-руководители склонны менее требовательно в профессиональном плане относиться к работникам-мужчинам, нежели к женщинам.

5. Таким образом, в ситуации, когда во многих сферах профессиональной деятельности преобладают женщины-работники, мужчина-работник приобретает особую ценность, а идеи феминизма объективно не получают широкой поддержки.

Информация о конфликте интересов. Авторы заявляют об отсутствии конфликта интересов.

Информация о спонсорстве. Исследование выполнено без участия спонсоров. 


\section{Список литературы}

1. Бекарев А.М., Лазукова Е.А. Трудовая карьера руководителей и специалистов в системе управления: компаративный анализ // Личность. Культура. Общество. 2015. Т. 17, № 1-2. С. 160-166.

2. Белова О.Е., Гуриева С.Д. Социальные представления о гендерном неравенстве в обществе и в организации // Материалы сборника статей участников международной научной конференции молодых ученых «Психология XXI века: актуальные вызовы и достижения». СПб: Изд-во ООО «Скифия-принт». С. 175-183.

3. Бочарова Е.Е. Самоопределение личности как субъекта профессиональной социализации // Проблемы социальной психологии личности : межвуз. сб. науч. тр. Саратов, 2012. Вып. 10. С. 121 128.

4. Воронина О.А. Политика гендерного равенства в современной России: проблемы и противоречия // Женщина в российском обществе, 2013. № 3. C. 12-20.

5. Гарипова Л.Г. Гендерный фактор профессиональной карьеры // Известия высших учебных заведений. Социология. Экономика. Политика. 2010. №2. С. 22-23.

6. Гуриева С.Д., Удавихина У.А. Особенности применения гендерных стратегий при построении карьеры женщинами в России // Герценовские чтения: психологические исследования в образовании. 2020. Выпуск 3. С. 270-273.

7. Гуцыкова С.В. Концептуализация представлений о безопасности социально-психологического пространства профессиональной деятельности // Актуальные проблемы психологии труда, инженерной психологии и эргономики / под ред. А. А. Обознова, А. Л. Журавлева. М., 2014. Вып. 6. С. 125-139.

8. Казанцева Т.В., Гуриева С.Д., Марарица Л.В. Субъективное переживание гендерного неравенства работающими женщинами // Петербургский психологический журнал. 2020. № 3. С. 35-52.

9. Козлова Ю.В., Савченко И.А., Горохова А.М. Динамика массового сознания в период пандемии // Современные исследования социальных проблем. 2020. Т. 12. № 2. С. 182-203. 
10. Корчагина Г.И., Макарова Е.В. Понятие карьеры в психологических исследованиях // Научно-методический электронный журнал «Концепт». 2016. Т. 32. С. 94-106. URL: http://e-koncept.ru/2016/56671.htm.

11. Марарица Л.В., Гуриева С.Д., Казанцева Т.В. Феномен гендерного неравенства как фактор карьерного капитала женщины: постановка проблемы // Психология человека в образовании. 2019. Т. 1, № 1. С. 44-52.

12. Маслоу А.Г. Мотивация и личность; Пер. с англ. А.М. Татлыбаева; вступ. ст. Н.Н. Акулиной. СПб.: Евразия, 1999. 478 с.

13. Погудина Е.Ю. Микроподход к организационному поведению // Вестник Томского государственного университета. 2013. № 373. C. 171-173.

14. Ромашкина Г.Ф., Ушакова Ю.В. Взаимосвязь социальных факторов и удовлетворенности условиями работы // Вестник Омского университета. Серия «Экономика». 2018. № 1 (61). С.182-195.

15. Савченко И.А. «Женское» и «не женское» лица войны в фокусе духовных ориентиров наших современников // Женское и мужское в традиционной и современной культуре: сохранение, фиксация, понимание. Материалы XIII международной научной конференции РАИЖИ и ИЭА РАН. В 2-х частях. Ответственный редактор Н.Л. Пушкарева, составитель А.И. Громова. 2020. С. 280-283.

16. Савченко И.А. Интеграция женских типов в концепте «героид»: социокультурные контексты и динамика // Современные исследования социальных проблем. 2010. № 3. С. 156-162.

17. Савченко И.А., Горбачев В.В. Образовательные контексты профессиональной мотивации сотрудников полиции в фокусе гендерных различий // Юридическая наука и практика: Вестник Нижегородской академии МВД России. 2020. № 3 (51). С. 151-155.

18. Толочек В. А. Ритмология профессиональной карьеры: эмпирические и методологические основания научного похода // Вестник Самарской гуманитарной академии. Серия Психология. 2015. № 1.(17). С. 3-10.

19. Толочек В.А. Социально-демографические доминанты темпоральных характеристик карьеры // Известия Саратовского университета. 
Новая серия. Серия Акмеология образования. Психология развития. 2016. Т. 5, вып. 3 (19). С. 121-128.

20. Фромм Э. Иметь или быть? М.: АСТ: Астрель, 2011. 314 с.

21. Хасбулатова О.А. Технологии создания мифа о равноправии полов: советские практики // Женщина в российском обществе, 2018. № 4. C. 49-59.

22. Ans De Vos, Beatrice IJM Van der Heijden, Current thinking on contemporary careers: the key roles of sustainable HRM and sustainability of careers // Current Opinion in Environmental Sustainability. Volume 28, October 2017. P. 41-50. https://doi.org/10.1016/j.cosust.2017.07.003.

23. Gendered Approaches to Spatial Development in Europe: Perspectives, Similarities, Differences / by Barbara Zibell (Editor), Doris Damyanovic (Editor), Ulrike Sturm (Editor). (Routledge Studies in Gender and Environments). Milton Park, Abingdon: Routledge; 1st edition. 2019. 276 p.

24. Global Gender Gap Report (2020). [Электронный ресурc]. URL: http:// www3.weforum.org/docs/WEF_GGGR_2020.pdf (дата обращения 22.01.2021).

25. Hard-to-Survey Populations / Eds.: R. Tourangeau et al. Cambridge: Cambridge University Press, 2014. 676 p.

26. Jobs, Careers, and Callings: People's Relations to Their Work / A. Wrzesniewski et al. // Journal of Research in Personality. 1997. Vol. 31. № 1. P. 21-33.

\section{References}

1. Bekarev A.M., Lazukova E.A. Lichnost'. Kul'tura. Obshchestvo [Personality. Culture. Society]. 2015. Vol. 17, No. 1-2. P. 160-166.

2. Belova O.E., Gurieva S.D. Materialy sbornika statey uchastnikov mezhdunarodnoy nauchnoy konferentsii molodykh uchenykh «Psikhologiya XXI veka: aktual'nye vyzovy i dostizheniya» [Materials of the collection of articles of the participants of the international scientific conference of young scientists "Psychology of the XXI century: actual challenges and achievements"]. SPb: Publishing house of LLC “Scythia-print”. P. 175-183.

3. Bocharova E.E. Problemy sotsial'noy psikhologii lichnosti: mezhvuz. sb. nauch. tr. [Problems of social psychology of personality: interuniversity. Sat. scientific. tr.]. Saratov, 2012. Issue 10. P. 121-128. 
4. Voronina O.A. Zhenshchina v rossiyskom obshchestve [Woman in Russian Society], 2013. No. 3. P. 12-20.

5. Garipova L.G. Izvestiya vysshikh uchebnykh zavedeniy. Sotsiologiya. Ekonomika. Politika [News of higher educational institutions. Sociology. Economy. Politics]. 2010. No. 2. P. 22-23.

6. Gurieva S.D., Udavikhina U.A. Gertsenovskie chteniya: psikhologicheskie issledovaniya v obrazovanii [Herzen Readings: Psychological Research in Education]. 2020. Issue 3. P. 270-273.

7. Gutsikova S.V. Aktual'nye problemy psikhologii truda, inzhenernoy psikhologii i ergonomiki [Actual problems of labor psychology, engineering psychology and ergonomics] / ed. A. A. Oboznova, A. L. Zhuravleva. M., 2014. Issue. 6. P. 125-139.

8. Kazantseva T.V., Gurieva S.D., Mararitsa L.V. Peterburgskiy psikhologicheskiy zhurnal [Petersburg Psychological Journal]. 2020. No. 3. P. 35-52.

9. Kozlova Yu.V., Savchenko I.A., Gorokhova A.M. Sovremennye issledovaniya sotsial'nykh problem [Modern studies of social problems]. 2020. Vol. 12. No. 2. P. 182-203.

10. Korchagina G.I., Makarova E.V. Kontsept [Concept]. 2016. Vol. 32. P. 94-106. URL: http://e-koncept.ru/2016/56671.htm.

11. Mararitsa L.V., Gurieva S.D., Kazantseva T.V. Psikhologiya cheloveka v obrazovanii [Human psychology in education]. 2019. Vol. 1, No. 1. P. 44-52.

12. Maslow A.G. Motivatsiya i lichnost [Motivation and personality]; Per. from English A.M. Tatlybaev; entry Art. N.N. Akulina. Saint Petersburg: Eurasia, 1999. 478 p.

13. Pogudina E.Yu. Vestnik Tomskogo gosudarstvennogo universiteta [Bulletin of the Tomsk State University]. 2013. No. 373. P. 171-173.

14. Romashkina G.F., Ushakova Yu.V. Vestnik Omskogo universiteta. Seriya «Ekonomika» [Bulletin of Omsk University. Series "Economics"]. 2018. No. 1 (61). P. 182-195.

15. Savchenko I.A. Zhenskoe i muzhskoe v traditsionnoy i sovremennoy kul'ture: sokhranenie, fiksatsiya, ponimanie. Materialy XIII mezhdunarodnoy nauchnoy konferentsii RAIZhI i IEA RAN [Feminine and masculine in traditional and modern culture: preservation, fixation, understanding. Materials of the XIII International Scientific Conference of RAIZH and IEA RAS]. In 2 parts. Responsible editor N.L. Pushkarev, compiled by A.I. Gromova. 2020. P. 280-283. 
16. Savchenko I.A. Sovremennye issledovaniya sotsial'nykh problem [Modern studies of social problems]. 2010. No. 3. S. 156-162.

17. Savchenko I.A., Gorbachev V.V. Yuridicheskaya nauka i praktika: Vestnik Nizhegorodskoy akademii MVD Rossii [Legal Science and Practice: Bulletin of the Nizhny Novgorod Academy of the Ministry of Internal A]ffairs of Russia. 2020. No. 3 (51). P. 151-155.

18. Tolochek V.A. Vestnik Samarskoy gumanitarnoy akademii. Seriya Psikhologiya. 2015. No. 1. (17). P. 3-10.

19. Tolochek V.A. Izvestiya Saratovskogo universiteta. Novaya seriya. Seriya Akmeologiya obrazovaniya. Psikhologiya razvitiya. 2016. Vol. 5, no. 3 (19). P. 121-128.

20. Fromm E. Imet' ili byt'? [To have or to be?]. M.: AST: Astrel, 2011. 314 p.

21. Khasbulatova O.A. Zhenshchina v rossiyskom obshchestve [Woman in Russian society], 2018. No. 4. P. 49-59.

22. Ans De Vos, Beatrice IJM Van der Heijden, Current thinking on contemporary careers: the key roles of sustainable HRM and sustainability of careers. Current Opinion in Environmental Sustainability. Volume 28, October 2017. P. 41-50. https://doi.org/10.1016/j.cosust.2017.07.003.

23. Gendered Approaches to Spatial Development in Europe: Perspectives, Similarities, Differences / by Barbara Zibell (Editor), Doris Damyanovic (Editor), Ulrike Sturm (Editor). (Routledge Studies in Gender and Environments). Milton Park, Abingdon: Routledge; 1st edition. 2019. 276 p.

24. Global Gender Gap Report (2020). URL: http:/www3.weforum.org/ docs/WEF_GGGR_2020.pdf (date of treatment 01/22/2021).

25. Hard-to-Survey Populations / Eds .: R. Tourangeau et al. Cambridge: Cambridge University Press, 2014.676 p.

26. Jobs, Careers, and Callings: People's Relations to Their Work / A. Wrzesniewski et al. Journal of Research in Personality. 1997. Vol. 31. No. 1. P. 21-33.

\section{ДАННЫЕ ОБ АВТОРАХ}

Савченко Ирина Александровна, доктор социологических наук, доцент, начальник научной лаборатории «Технологии социально-гуманитарных исследований»; профессор кафедры психологии и педагогики 
Нижегородский государственньй лингвистический университет им. Н.А. Добролюбова; Нижегородская Академия МВД РФ ул. Минина, 34а, г. Нижний Новгород, 603000, Российская Федерация; Анкудиновское шоссе, 3, г. Нижний Новгород, 603144, Российская Федерация

teosmaco@rambler.ru

Козлова Юлия Владиславовна, кандидат психологических наук, доцент, старший научный сотрудник научной лаборатории «Технологии социально-гуманитарных исследований» Нижегородский государственньй лингвистический университет им. Н.А. Добролюбова

ул. Минина, 34а, г. Нижний Новгород, 603000 Российская Федерачия

Iris08@yandex.ru

\section{DATA ABOUT THE AUTORS}

Savchenko Irina Aleksandrovna, Dr. Habil. (Sociology), Head of the International Cross-Disciplinary Laboratory "Research Methods in Social Science", Professor of the Department of Philosophy, Sociology and the Theory of Social Communication; Professor of the Department of Philosophy

Linguistics University of Nizhny Novgorod; Nizhniy Novgorod Academy of the Ministry of the Interior Affairs of Russia 34a, Minin Str., Nizhny Novgorod, 603000, Russian Federation; 3, Ankudinovskoe shosse, Nizhny Novgorod, 603144, Russian Federation

teosmaco@rambler.ru

Kozlova Yulia Vladislavovna, $\mathrm{PhD}$ (Pedagogy), Senior Research Associate of the International Cross-Disciplinary Laboratory "Research Methods in Social Science"

Linguistics University of Nizhny Novgorod

34a, Minin Str., Nizhny Novgorod, 603000, Russian Federation Iris08@yandex.ru 